\title{
STATURE IN NINETEENTH-CENTURY RIO DE JANEIRO: PRELIMINARY EVIDENCE FROM PRISON RECORDS*
}

ZEPHYR FRANK

Stanford University ${ }^{\mathrm{a}}$

\begin{abstract}
RESUMO
Esta análise sobre condições de vida no Rio de Janeiro, no século XIX, baseia-se em dados antropométricos e descritivos obtidos na documentação da Casa de Detenção. A pesquisa mostra que houve mudanças significativas nas alturas de presos ao longo do tempo e em função de sua cor e nacionalidade. Principalmente, houve um declínio na estatura de escravos, a partir dos nascidos nos anos 1830 e continuando ate os anos 1860 , onde se interrompe o presente estudo. As diferenças entre escravos e homens livres por um lado, e entre brasileiros nativos no Rio de Janeiro e brasileiros nascidos fora da capital por outro lado, mostram que, além do declínio percebido na estatura dos escravos, houve também uma "penalidade urbana» na estatura, indicada pelo fato de serem os presos nascidos no Rio de Janeiro menos altos do que os outros presos

Timely comments on drafts of this paper were provided by Herbert Klein, Moramay López-Alonso, John Komlos, Richard Steckel, and Nancy Tatarek. The two anonymous readers for RHE-JILAEH also provided excellent criticism and advice. Sidney Chalhoub read multiple drafts and provided input regarding the argument of the paper. Professor Chalhoub and the Cecult team at UNICAMP, Brazil, generously provided the raw data for this study as part of an ongoing international collaborative endeavor, "Terrain of History», based at UNICAMP, Stanford, and Brown University. Michael Dinerstein provided research assistance at Stanford. Any remaining errors or infelicities are mine alone.

a History Department, Stanford University, Stanford, CA 94305-2024(USA); zfrank@stanford.edu.
\end{abstract}


brasileiros. Falta de alimentação, aumento no custo de vida em geral, transferência de escravos para fora da cidade depois de 1850, e epidemias urbanas eram fatores que influíam nas alturas dos presos.

Palavras chave: antropometria, condições de vida, alturas presos, Brasil século XIX

\begin{abstract}
Based on anthropometric data and descriptive information contained in the records of the Rio de Janeiro city jail (Casa de Detenção), this paper explores patterns of change in living conditions during the nineteenth century. The research shows that there were significant changes in the heights of prisoners over time and according to race and nationality. Most importantly, heights of Brazilian-born slaves declined for the cohorts born in the 1830s through the beginning of the 1860s. In addition, differences in heights for natives of the city of Rio de Janeiro and for other Brazilian prisoners provide evidence of an «urban penalty» in stature during this period. Poor nutrition, the high cost of food and shelter, the movement of some slaves out of the city and into plantation work after 1850 , and urban epidemics are assessed as the factors influencing trends in prisoner heights. Throughout the analysis, height trends discovered in Rio de Janeiro are placed in international comparative perspective.
\end{abstract}

Keywords: anthropometric, living conditions, heights prisoners, Brazil 19th century

JEL Classification: I12, N36

\title{
1. INTRODUCTION
}

What can physical stature tell us about social and economic conditions in nineteenth-century Rio de Janeiro? This paper argues that the heights of poor prisoners listed in the register of the city jail provide a valuable source to investigate trends in the nutrition and social conditions of the poor majority, and slaves in particular, that made up Rio de Janeiro's growing urban population during a pivotal period in Brazil's history. Men and women, slaves and free persons were booked into the city jail by the thousands. Because the jailers recorded prisoner heights, we can assess the nutrition and living conditions of a wide spectrum of poor residents of Brazil's nineteenth-century capital and first metropolis.

In specific terms, the height data for Rio de Janeiro's prisoners can contribute to debates on Brazil's economic development and the experience of slavery and poverty. One of the guiding ideas behind this rese- 
arch, and I believe behind much of the recent work in anthropometric history, is a concern for the quality and distribution of material conditions over and above aggregate measures of economic growth or wealth. Even if the population of the city of Rio grew by leaps and bounds and exports flowed in ever greater quantities from its port, we want to know how this growth was distributed and how these changes affected common people ${ }^{1}$. The study of prisoner heights can help accomplish these goals.

There is an external dimension to this project, in which the heights of prisoners in Rio are contrasted with heights in other contemporary societies. For instance, the heights of Brazilian-born slaves and free persons can be compared with their counterparts born elsewhere around the same time. Differences between these populations can provide evidence of the relative living standards in Brazil; even in the first half of the nineteenth century, well before alternative measures, such as GDP per capita are available with any degree of precision. The logical set of cases for comparison would include the United States, another large slave society (in the South), Southern Europe, from which Brazil attracted the most immigrants in the nineteenth century, and other Latin American countries for regional context.

Internal contrasts between the heights of prisoners are just as revealing. The prisoner lists include information on the place of birth of each individual, allowing for an analysis of the heights of prisoners from different regions of Brazil. This allows for the isolation of prisoners born in the urban environment of Rio de Janeiro in order to test hypotheses about the effects of conditions specific to the city - especially the «urban penalty» found in many other studies of heights during the nineteenth century. Most importantly, the localized and detailed data concerning individual prisoners allows for a close analysis of the heights of the slave and free populations while controlling for a range of important variables, including place of birth, color, birth cohort, and occupation. Tracking slave heights contributes to resolving questions about the changing status of slaves over the course of the nineteenth century. Were slaves worse off than their free cousins? Did their conditions improve or worsen over time and as a result of major events like the ending of the Atlantic slave trade in 1850 ?

Some background regarding the overall social, economic, and institutional situation in Rio de Janeiro is required to place arguments drawn from prisoner heights in broad perspective. The period under review begins with cohorts of prisoners born in the decade before Brazilian independence, although, admittedly, the sample size is quite small for this earliest period. It traverses the three decades, from the $1820 \mathrm{~s}$ through the

1 For an eloquent statement of the importance of studying the material conditions of life, particularly of the poor, see Coatsworth (1996, pp. 1-12). 
1840s, during which the Atlantic slave trade remained open, profoundly influencing the demography and economy of Rio de Janeiro. The last cohort, born in the 1850 s, reflects a new institutional setting in which the slave trade had been suppressed and the economy of the city had taken on an even greater dynamism owing to urban growth, entrepreneurial innovation, railroad construction, and the expansion of the coffee economy in rural Rio de Janeiro province and beyond. Bowing to British and domestic pressure, the Atlantic slave trade ended in 1850. Among the results of the ban was a rise of more than 100 percent in slave prices in Rio de Janeiro over a few short years ${ }^{2}$. Exports through the port of Rio de Janeiro were valued at 22,599 contos in 1845; by 1860 the value of exports from the capital had expanded nearly threefold to 57,599 contos $^{3}$.

In addition to these large scale processes, I also wish to highlight several important local characteristics of the city of Rio de Janeiro. First, this was a city built by immigrants, many forced to its shores as slaves from Africa, many others arriving from Portugal and other European countries. As such, it is necessary to pay close attention to the place of birth of prisoners. Second, the very rapid growth in Rio de Janeiro's urban population, rising from 86,323 residents in 1821 to 274,972 in 1872 , or an annual rate of 2.3 percent, meant increasing urban crowding and public health problems, culminating, in the period under consideration with devastating epidemics of yellow fever and cholera around the middle of the nineteenth century ${ }^{4}$. Rapid urban growth also meant high prices for food and shelter, with particularly rapid inflation noted in the 1850s. The disease environment and high cost of food, particularly protein rich meat, cheese, and eggs, form part of our general explanation for the relatively short final heights of all groups in our sample.

\section{THE DATA: SOURCES AND METHODS}

The use of height data is now well established among social science historians ${ }^{5}$. Researchers have shown a clear connection between nutrition and living standards in the growing years and the final heights of groups of people such as army conscripts and slaves ${ }^{6}$. Most studies of

${ }^{2}$ Frank (2004, p. 100). An estate inventory sample for 1845-49 yields a mean price of 421 mil-réis; the sample for $1855-60$ yields 978 mil-réis.

3 Lahmeyer Lobo (1978, p. 266).

41821 urban population reported in Karasch (1987, p. 66). 1872 census figure from Anuário Estatístico do Brasil, 1908-12 (Rio de Janeiro: Dir. Geral de Estatistica, 1916), vol. 1, p. 18.

${ }^{5}$ For an overview of the literature see Floud (2002, pp. 152-164).

6 The relationship between nutrition and final heights has long been a subject of concern for human biologists. For a good introduction to this literature, see Eveleth and Tanner (1990). 
heights are limited, however, by a reliance on truncated samples drawing from just one part of the population -in the case of army conscripts, for instance, there is usually a minimum height requirement for conscription. This limitation has been overcome with the use of sophisticated statistical techniques, yet there remain questions which cannot be addressed directly using these sources and methods ${ }^{7}$. For example, the stature of women usually remains unexamined, although this is less the case in the literature on slave heights, which derives from different sorts of records ${ }^{8}$.

Turning now to the Rio de Janeiro data, height information in this paper is derived from a machine-readable sample of prisoner records compiled by the Cecult research group at the State University of Campinas, São Paulo, Brazil. The original books of the Casa de Detenção (city jail) of Rio de Janeiro were microfilmed and selected years were entered into a database. The years sampled include 1860-61 and 187780. In raw form, the file contained many duplicate prisoners (men and women arrested on more than one occasion) as well as juvenile and elderly prisoners. Removing duplicates and foreigners and restricting the analysis to males aged 20 to 50 years resulted in a total usable sample of 1,142 prisoners. The relatively small size of the sample precludes the analysis of several important dimensions of the history of heights in the Rio jail owing to small cell sizes. The small size of the sample should also be kept in mind when considering the general claims advanced in this paper. Notwithstanding these limitations, the sample is sufficiently large to address some of the most important questions regarding height and living standards in nineteenth-century Brazil for the first time.

Prisoners were measured in Portuguese feet and inches (pés and polegadas) and, at other times, in meters ${ }^{9}$. The Portuguese inch (polegada) corresponded to 1.08 English inches or 2.75 centimeters ${ }^{10}$. All measure-

7 Discussions of statistical techniques for dealing with truncation and age/height heaping (e.g., clustering on round numbers) can be found in Fogel et al.(1983, pp. 455-462); Komlos (2004, pp. 160-173); and in López-Alonso (2000, pp. 50-59).

8 For the dearth of alternative sources on heights in the literature, see Cole (2000, pp. 317-324). A recent exception to this rule, which also draws on prisoner heights, is Johnson and Nicholas (1997, pp. 201-250).

9 We lack descriptions of the actual process of measurement. For the purposes of this article, it is assumed that all measurements were made with prisoners in bare feet (slaves did not generally wear shoes). Since the measurements often include precise numbers, down to the half-inch, it is further assumed that the measurements were made by physical measurement and that values were not merely ascribed to prisoners according to visual impressions or prisoner's declarations.

10 Zupko (1977). The mean height of prisoners originally measured in meters was 1.647; the mean height, converted to meters at a rate of 1 polegada equals $2.73 \mathrm{~cm}$, of those measured originally in Portuguese feet, was 1.645 . At a rate of $2.75 \mathrm{~cm}$ to the polegada, the average height of these prisoners was 1.656 meters. 
ments analyzed in this study were standardized to meters and centimeters. There were multiple cases of prisoners measured in feet and inches and, at a different time, in meters. An analysis of these cases indicates that the actual rate of conversion was approximately 1.075 rather than 1.08 polegadas to the English inch, or 2.73 centimeters per polegada. The prison may have had a slightly defective instrument - as a conversion factor below 1.08 is found in every single case and it seems reasonable to assume that the metric measurements are the more accurate of the two. On this basis, the conversion used in this paper to render prisoner heights in a metric equivalent is 1 polegada equals 2.73 centimeters. It seemed more appropriate to use a consistent conversion factor based on the actual practice of measurement in the Rio prison rather than employ the official conversion. Of all the Brazilian-born male prisoners in the core sample, 543 were originally recorded in meters, whereas 599 were originally recorded in Portuguese feet ${ }^{11}$.

For the most part, this sample of adult male prisoners born in Brazil will form the basis of the analysis pursued in this paper ${ }^{12}$. Exceptions to this include an analysis of the heights of foreign-born prisoners as well as heights of native-born women.

The most common «crime» for which people were arrested was vagrancy, followed by disorder and public drunkenness ${ }^{13}$. Time spent in jail usually did not extend beyond a week. These, then, were mainly arrests for petty crimes. Arrests were distributed among all groups of the city's poor population, although slaves were arrested in disproportionately high numbers ${ }^{14}$. The sample is clearly limited to the poorer reaches

11 The data were also analyzed using the 2.75 centimeters to the polegada conversion factor. Using this conversion, mean heights overall are about $0.6 \mathrm{~cm}$ higher. Because the majority of cases measured in polegadas occur in the earlier sample years, using 2.75 rather than 2.73 increases the trend in declining heights. In order to test whether using different conversion rates would alter the results in any significant way, the same regression reported in Table 2 was run using the 2.75 conversion rate. There was no significant difference in the results obtained. The same dummy variables were significant and to almost identical degrees.

12 A small but growing number of studies use prisoner heights in the United States. See, e.g. Komlos and Coclanis (1997, pp. 433-459); Carson (2005, pp. 405-419); and Tatarek (2006, pp. 222-236).

${ }^{13}$ The most common reasons for imprisonment (vagrancy, disorder, drunkenness) accounted for 47 percent of all cases. Another common category of prisoner was suspected fugitive slave (12 percent). Serious crimes were far less common: property crimes ( 2.1 percent) and violent crimes ( 0.6 percent) made up a very small fraction of all arrests. Some cases (14 percent) did not indicate the reasons for imprisonment.

14 According to the 1872 census, male slaves made up 16 percent of all males in the city; at about the same time, slaves made up 51.2 percent of adult male prisoners. Brazil, Recenseamento da população do Brazil a que se procedeu no dia 1 de agosto de 1872 (Rio de Janeiro: Diretoria Geral de Estatística, 1873-76). For discussions of police repression in Rio, see Holloway (1993); Chalhoub (1990); and Líbano Soares (2002). 
of society, and no claim is made that the height data reflect the stature of the wealthy minority of Rio de Janeiro ${ }^{15}$. Nevertheless, this is a sample that broadly reflects the majority of city residents, at least in terms of their life conditions ${ }^{16}$.

Using this source, it is possible to address three important questions regarding social and economic conditions for the poor majority in Rio de Janeiro. Firstly, what were the general trends in height over time? Secondly, how did heights differ according to the characteristics of prisoners, particularly whether slave or free? Thirdly, did these trends and patterns correspond to larger shifts in the social, institutional, economic, and epidemiological environment of the city? Because final heights are attained by the early twenties, and because shrinkage does not set in until the fifties, the heights of cohorts born in certain periods (this paper will use decades) allow the projection of measurements taken in adulthood backward into the past, to when the cohort was in its growing years. Thus, a forty-year-old slave measured in 1880 can tell us something about the social conditions and nutrition of slaves in the 1840s and 1850s. When a sufficient number of observations are available, it is possible to estimate trends in social conditions over time as well as disaggregate cohorts to study the variation in conditions among different social groups.

In the table and figure below, summary statistics about the core sample of adult males are provided. Here and throughout the remainder of the text, the category of analysis is assumed to be Brazilian-born adult males unless otherwise noted.

Free men in the Rio jail averaged 1.649 meters in height, with slight variations according to place of birth and birth decade, suggesting that the period from the 1820s-50s was one of stagnation in living standards for the poor free population ${ }^{17}$. Slaves show much greater variation, both according to birth cohort and birthplace. Perhaps surprisingly, slaves born before the 1840 s were taller than their free counterparts ${ }^{18}$. Slaves

15 López-Alonso's study (2000, p. 84) of Mexican heights indicated that the better off were about six centimeters taller than poor army conscripts. More directly to the point, a recent study of heights in Brazil between 1938 and 1982, Nogueról et al. (2005), found that the gap between the heights of the poorest and richest quintile was six centimeters.

${ }_{16}$ Tatarek (2006) comes to a similar conclusion regarding representativeness (among the poor) in the case of Ohio prisoners.

17 For a summary of the literature on living standards in Latin America, see Coatsworth (2005, pp. 126-144, esp. 128-131). The height data for prisoners in Rio de Janeiro's jail add further evidence to support Coatsworth's contention that living standards stagnated through most of the nineteenth century. This should not, however, be taken as evidence that the aggregate economy of the city of Rio de Janeiro also stagnated, since this was not the case.

${ }^{18}$ In an unsubstantiated passage, Mattoso (1986) writes that «We know that the slave diet was far richer in calories, proteins, and carbohydrates than the diet of a poor Brazilian in the twentieth century". 


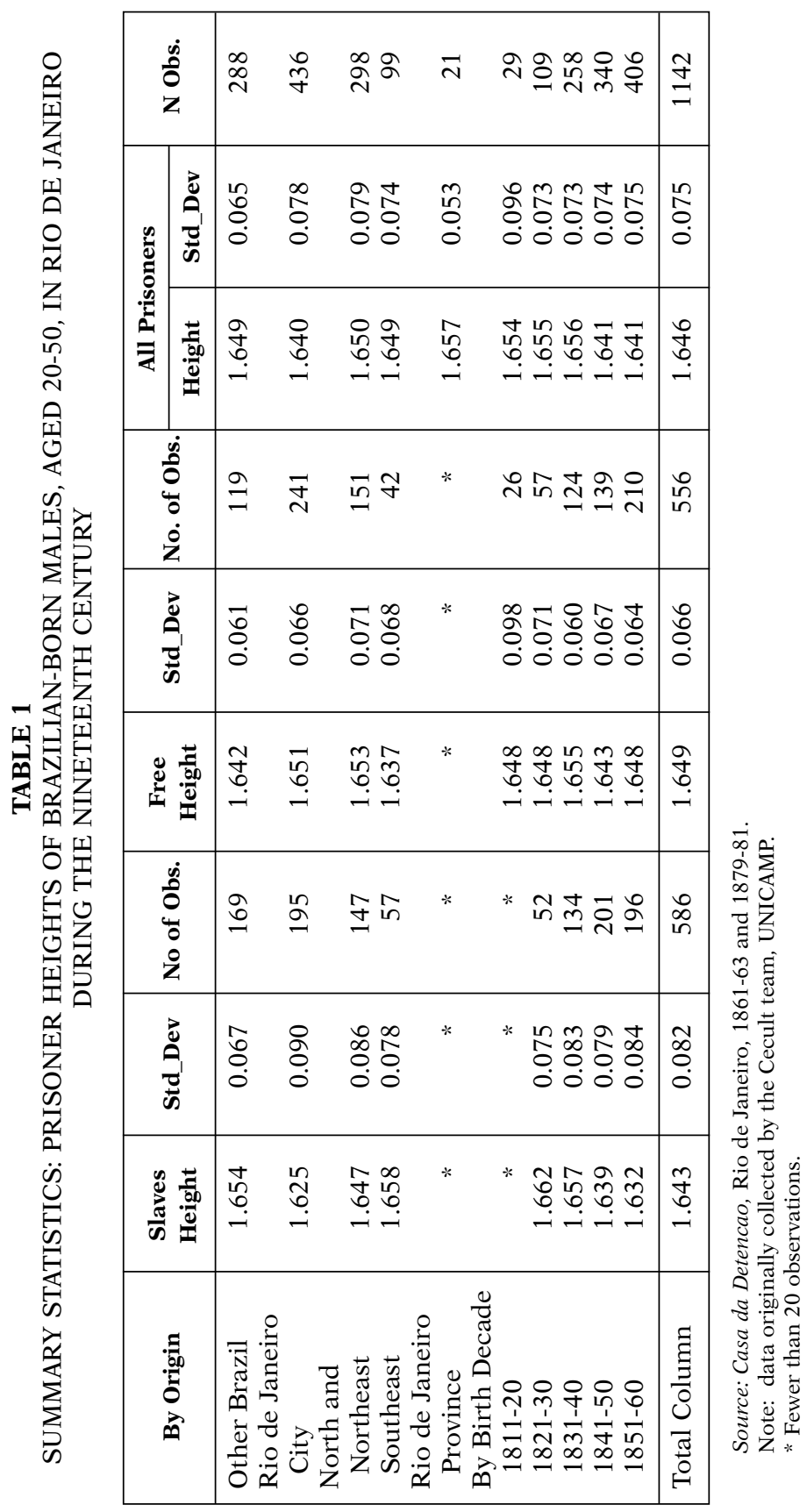


FIGURE 1

THE DISTRIBUTION OF MALE HEIGHTS IN RIO DE JANEIRO JAIL (meters)

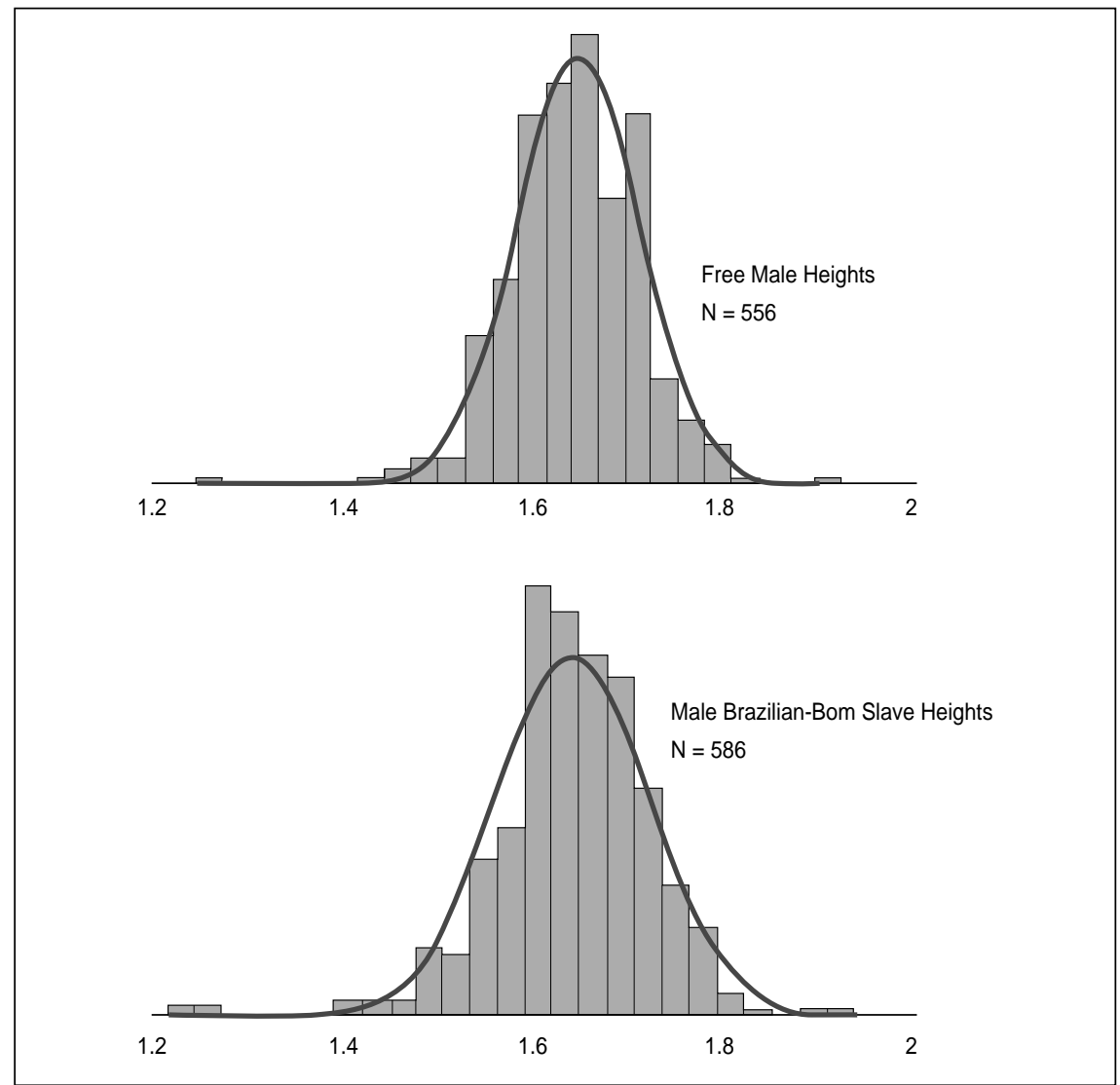

born in the city of Rio de Janeiro, however, tended to be shorter than their free counterparts in all periods. The slaves from the NorthNortheast, who were moved by their owners or sold to buyers in Rio de Janeiro, tended to be taller than their counterparts native to Rio de Janeiro city and taller or as tall as the free prisoners in the sample. The results of a simple regression, which attempts to control for a range of variables that might hypothetically influence height, help to clarify the main issues.

The dummy variables «skilled manual laborer» «black» (in the Brazilian context this designation of color is only tenuously linked to 
TABLE 2

DETERMINANTS OF PRISONER HEIGHTS: A PRELIMINARY ASSESSMENT

\begin{tabular}{|l|r|r|r|r|}
\hline \multicolumn{1}{|c|}{ Dummy } & \multicolumn{1}{c|}{ Coef. } & \multicolumn{1}{c|}{ Std. Err. } & \multicolumn{1}{c|}{ t } & \multicolumn{1}{c|}{ P>lt| } \\
\hline Rio City & -0.01454 & 0.005233 & -2.78 & 0.006 \\
Northeast/North & -0.00043 & 0.005718 & -0.08 & 0.94 \\
Skilled Manual Laborer & 0.0197 & 0.006341 & 3.11 & 0.002 \\
Unskilled Manual Laborer & 0.004239 & 0.005083 & 0.83 & 0.404 \\
Black & 0.010369 & 0.004743 & 2.19 & 0.029 \\
Free & 0.007995 & 0.004794 & 1.67 & 0.096 \\
Cohort 30s & 0.002331 & 0.007794 & 0.3 & 0.765 \\
Cohort 40s & -0.01405 & 0.00762 & -1.84 & 0.065 \\
Cohort 50s & -0.01236 & 0.007316 & -1.69 & 0.092 \\
\hline cons & 1.64666 & 0.00822 & 200.33 & 0 \\
\hline
\end{tabular}

R-squared $=0.0292$

N Obs. $=1142$

Source: See Table 1.

phenotype), and «free» were attributes with significant positive height effects. Being born in Rio de Janeiro and birth in the latter two decadal cohorts were attributes which had significant negative effects. These results, however, must be interpreted with great caution. The sample size is small and the amount of variation in height «explained» by the model is minimal.

The basic puzzle that emerges from the summary statistics in Table 1 and the regression results regarding these prisoners is why slave heights declined rather substantially over the course of the middle decades of the nineteenth century and why prisoners born in Rio de Janeiro tended to be shorter and to experience declining stature. Now that the general results have been traced out, it is worth spending some time placing them in an international comparative context.

\section{INTERNATIONAL COMPARISONS}

Whether slave or free, the Brazilian-born prisoners in the sample were shorter than their counterparts in the United States. The substantial research on slave heights in the United States suggests a range from 65 to 68 inches, or 1.651 to 1.727 meters ${ }^{19}$. If we accept the consensus

19 Fogel et al. (1983, pp. 445-481). The lower bound figure is offered by Tadman (2000, pp. 1534-1575) according to shirt measurements. It should be noted that the vast preponderance of the evidence and the literature sustains the upper-bound estimate rather than 
estimates of about 1.72 meters, then native Brazilian slaves were between 5 and 12 centimeters shorter than their North American counterparts, depending on their place of birth and birth cohort. At the most extreme and translated into inches, slaves born in Rio de Janeiro during the 1850 s appear to have been nearly five inches shorter than slaves in the United States.

Free white men from urban areas averaged about 1.72 meters in the United States during the 1850 s and $1860 \mathrm{~s}^{20}$. Free Brazilians (including the free colored) resident in Rio de Janeiro measured 7 centimeters shorter than North Americans. The gap between the free in the United States and Brazil appears to have been similar to the gap between slaves in the two countries.

The evidence drawn from Rio's prison records shows that, at least in the first decades of the nineteenth century, heights of slaves were not substantially lower than those of the free; indeed, slaves were generally taller than free prisoners in the 1820s. This finding suggests that, in Rio de Janeiro, the nutrition obtained by slaves and the free poor was similar, at least at the start of the 1800s, and that, as with North America, the impact of slavery was felt more directly in the form of coerced labor and general exploitation than in systematic malnourishment in the earliest decades of the nineteenth century. What malnourishment there was in Rio de Janeiro seems to have been spread equally among the poor prior to the divergence seen in heights starting in the 1830 s and accelerating into the 1840s and 1850s. Thus, the chief puzzle presented to us by the changing stature of prisoners in Rio de Janeiro is the question of why slaves and free diverged in terms of mean heights after a period of very similar stature and, ceteris paribus, similar experiences of nutrition, shelter, and disease ${ }^{21}$.

As provocative as comparisons between Brazil and the United States are, international comparisons need to be expanded beyond the BrazilNorth America axis. Keeping close to the United States, but considering a very different demographic and economic setting, we can place the Brazilian height figures in the context of results reported by Higman for the Caribbean. In a pioneering study, based on a large sample, Higman reported adult male slave heights of 1.633 meters for Africans and 1.659

Tadman's alternative. For a comprehensive analysis of slave heights in the United States, see Steckel (September 1986, pp. 721-741). For additional references, see also, Komlos (1994, pp. 93-116); and Komlos (1992, pp. 297-329).

20 Margo and Steckel (1983, p. 169).

21 This assumes that the final heights attained by slaves and free tell most of the story. It is possible that slave children had very different height profiles from their free counterparts, even as they ended up with similar final adult heights. For an analysis of this issue in the North American case, see Steckel (1986, pp. 723-726). 
meters for Creole slaves in the Caribbean circa $1813^{22}$. These estimates are similar to those found among prisoners in the Rio jail for the cohort born in the 1820s - with Brazilian-born slaves taller than their African counterparts. With the taller United States slaves in mind, Higman suggests that relatively poor nutrition and hard work in the sugar fields and factories were to blame for the shorter stature of Creole slaves in the Caribbean ${ }^{23}$. In the city of Rio de Janeiro the work environment was not particularly harsh so the explanation of height shortfalls must hinge upon nutrition, the disease environment, and other factors determining the makeup of the urban population.

Turning our attention to the other side of the Atlantic, evidence on heights in Southern Europe illuminates the relative conditions of native Brazilians and their many European immigrant cousins. The stature of Italian conscripts, adjusted for age and regional effects, was 1.624 meters for the 1842 birth cohort ${ }^{24}$. In our sample of free, Brazilian-born prisoners, the mean height for the $1841-50$ period was 1.643 meters. The difference is not very large, but it suggests that the life conditions of free native-born Brazilians was better than, or at least on a par with, the life conditions in rural Italy.

Research on heights of conscripts in Spain during the nineteenth century yields estimates ranging from 162.3 centimeters for twenty-year-old conscripts born circa 1838 to 160.9 centimeters for those born circa $1870^{25}$. These conscripts, from rural, southern Spain, were significantly shorter than native-born free prisoners in the Rio de Janeiro jail, but the precise extent of the difference cannot be judged precisely because the age of the recruits in the Spanish data suggests they were still growing. Overall, the slight shortfall in Southern European heights vis-à-vis the Brazilian-born free poor makes sense to us in light of the subsequent major waves of immigration to Brazil from Portugal, Spain, Italy and elsewhere in Europe: migrants should seek to move where conditions (heights) are better (taller).

Portuguese immigrants in Rio measured 1.65 meters for the 1851-60 cohort, although they tended to be shorter than free native Brazilians in all other periods. The Southern European norm would appear to be around 1.61-1.63 meters for young adult males born circa $1850^{26}$. Native

\footnotetext{
22 Higman (1979, p. 374).

23 Ibid., 383.

24 Arcaleni (2006, p. 27). Reis (2004) found heights similar to those reported in this paper when examining nineteenth-century Portuguese heights in a recent working paper.

25 Martínez Carrión (2001, p. 57).

${ }_{26}$ The gap between Northern and Southern Europe was large and persistent. For instance, the mean height of 18-year-old conscripts in Portugal circa 1990 was 1.70 meters, whereas the mean height for Dutch conscripts of the same age was 1.81 meters. Cole (2000).
} 
STATURE IN NINETEENTH-CENTURY RIO DE JANEIRO: PRELIMINARY EVIDENCE...

TABLE 3

HEIGHTS OF AFRICANS AND PORTUGUESE IN RIO DE JANEIRO

\begin{tabular}{|c|c|c|}
\hline Birth Cohort & Birthplace: Africa & Birthplace: Portugal \\
\hline $1821-30$ & 1.647 & 1.638 \\
$1831-40$ & 1.623 & 1.639 \\
$1841-50$ & 1.593 & 1.638 \\
$1851-60$ & NA & 1.650 \\
\hline
\end{tabular}

Source: see Table 1.

Note: measurements refer to male prisoners, ages 20-50.

Number of observations: 676 .

Brazilian whites measured 1.64 meters for the 1851-60 birth cohort -a value similar to, though slightly higher than, their Southern European counterparts around the same time.

Moving to regional comparisons, what do we know about heights in other Latin American contexts? Ricardo Salvatore reports average heights of 1.676 meters for prisoners in the province of Buenos Aires, Argentina, circa 1849-51 and 1.673 meters circa 1889-91. By this measure, poor prisoners in the province of Buenos Aires were about 3 centimeters taller than their free counterparts in Rio de Janeiro ${ }^{27}$. Viewed from a different angle, the results of Salvatore's study of prisoner heights dovetail with those found in Rio de Janeiro in one critical aspect: in both cases, the mean height of free prisoners (slavery not being an issue in Argentina at the time) was fairly stable over time, suggesting stable, if not stagnant, living conditions among the poor in both countries over much of the nineteenth century.

Drawing on a very different source of data, passport records, Adolfo Meisel and Margarita Vega report average male heights of 1.674 meters for men born in Colombia in the years 1870-74, and 1.682 meters for males born between 1875 and $1880^{28}$. The birth years of these cohorts fall after the end of the period under consideration in this paper but within the general frame of the latter nineteenth century. Passport holders, as Meisel and Vega indicate, presumably represent the heights of the middle and upper classes, and so these figures are not directly comparable with those derived from prison records in Rio. Nevertheless, it seems plausible that the middle and upper classes of Colombia would be 2-3 centimeters taller than the average free prisoner in the Rio jail who happened to be born a decade earlier.

27 «Alturas, Nutrición y Bienestar en la Argentina (1790-1950): Algunos hallazgos recientes y su importancia para la historia económica», working paper, version 5 (2004), p. 9.

${ }_{28}$ "The Stature of the Colombian Elite before the Onset of Industrialization, 1870-1919», Banco de la República, Borradores de Economia, paper number 339, p. 7. 
In sum, the heights of native-born prisoners in Rio de Janeiro, both free and slave, were well shorter than North American men. However, free native-born Brazilians were taller than Southern Europeans, though by a relatively small margin. Brazilian prisoners were shorter than Argentine prisoners from around the same period of time, though the Argentine sample is drawn from a more rural population. Finally, poor prisoners in the Rio de Janeiro sample were shorter, as would be expected, than members of the elite in Colombia and Mexico ${ }^{29}$.

\section{EXPLAINING DECLINING SLAVE HEIGHTS}

There remains the puzzle of declining heights among Brazilian-born slaves in Rio de Janeiro which seems to have begun in the 1830s. Prior to this period, slave males had been slightly taller than their free counterparts, so an explanation that fits this larger pattern is needed. In order to explore this seemingly paradoxical trend, consider three hypotheses that might account for the decline or stagnation in the growth of slave heights: 1) deteriorating nutrition; 2) a changing disease environment, and 3) changes to the sample itself owing to a shift of taller, more robust slaves to the rural coffee sector. Because these theories are not mutually exclusive, it is likely that some combination of all three factors might explain the dip in slave heights among bondspersons born after 1830 .

It will not do to suggest that slaves had poorer nutrition, but only starting in the 1830s (or 1840s in the case of the North-Northeast subsample), unless something very substantial changed in the way slaves and free obtained food or in terms of the rationale behind the allocation of food by slave masters or slave parents of children and adolescents. Because slaves were the most vulnerable segment of the city's population, deteriorating nutrition cannot be ruled out as a factor in the shorter final heights reached by slaves ${ }^{30}$.

In the first place, it makes sense to distinguish more precisely the place of birth of the slaves and free prisoners under consideration. In

\footnotetext{
${ }^{29}$ It also bears noting that the heights of Rio de Janeiro's prisoners were low according to modern standards. Male slave prisoners born in Rio in the 1850 s, for instance, were two standard deviations below the modern standard of $174.7 \mathrm{~cm}$ for men. For the use of modern standards in the historical interpretation of heights and the adult male modern standard and standard deviation, see Steckel, «A Peculiar Sample», pp. 723-25. Health effects of declining height can be conceived of as being more severe, the farther from the modern standard. In the case of slaves born in Rio, the decline meant going from over one standard deviation below the modern standard, which was already bad enough, to being more than two deviations below it, indicating a severe shortfall in height.

30 According to Steckel (1989) the relationship between height and nutrition can be expressed in the following terms: «... heights are a measure of net nutrition, that is, actual diet minus claims on the diet made by illness, physical effort, and maintenance».
} 
Table 1, the heights of native-born slave and free prisoners were divided into those most likely born in the city of Rio de Janeiro and those born elsewhere ${ }^{31}$. Slaves born elsewhere in Brazil, including elsewhere in Rio de Janeiro province, appear to have been taller on average. Table 3 shows what happens when heights of slaves born in other parts of Brazil are contrasted with those born in Rio de Janeiro according to birth cohorts.

TABLE 4

HEIGHT BY PLACE OF BIRTH AND BIRTH COHORT

\begin{tabular}{|l|c|c|c|c|}
\hline \multirow{2}{*}{\multicolumn{1}{c|}{ Birthplace }} & \multicolumn{4}{c|}{ Birth Cohort } \\
\cline { 2 - 5 } & $\mathbf{1 8 2 1 - 3 0}$ & $\mathbf{1 8 3 1 - 4 0}$ & $\mathbf{1 8 4 1 - 5 0}$ & $\mathbf{1 8 5 1 - 6 0}$ \\
\hline City of Rio de Janeiro (slave) & 1.655 & 1.639 & 1.619 & 1.610 \\
North/Northeast (slave) & 1.674 & 1.662 & 1.640 & 1.642 \\
City of Rio de Janeiro (free) & 1.646 & 1.663 & 1.649 & 1.646 \\
North/Northeast (free) & 1.642 & 1.648 & 1.645 & 1.678 \\
\hline
\end{tabular}

Source: see Table 1. All cells $>10$ observations.

The fact that the heights of slaves were declining in both the Northeast and in the city of Rio de Janeiro, calls into question how much of the decline in mean slave heights can be attributed to conditions specific to Rio de Janeiro city as opposed to forces leading to declining heights of slaves more generally. This pattern might also lend support to the hypothesis that taller slaves were diverted out of the city and into the coffee fields after 1850. Slaves in the city of Rio started out shorter than their counterparts elsewhere in Brazil, but all slaves booked into the prison, regardless of origin, suffered declines in mean heights over time.

Rio de Janeiro, beginning in the 1840s and especially in the 1850 s, experienced aspects of all three hypotheses set forth to explain declining heights. Specifically, with respect to nutrition, the cost of food rose dramatically in Rio de Janeiro during the 1850s. According to Lobo's price index, base-year 1919, the price level more than doubled over the 1850s, with most of the run-up taking place during the period $1853-55^{32}$. The timing of this price shock in foodstuffs might well be reflected in the

31 Local origins are given in most cases. Locales outside of the city but within the province of Rio de Janeiro appear to have been distinguished on a systematic basis. Thus, a prisoner born on the Ilha do Governador, quite near the city, is listed as such and not as having been born in the city of Rio de Janeiro. Clearly, however, there is a chance that some of the prisoners listed as born in Rio de Janeiro were, in fact, born in the province, not the city.

32 Lobo (1978, p. 748). There are major problems with how Lobo constructed her indices and we urge caution in their use. In fact, another index, set according to an 1856 basket 
declining heights of slaves born in the 1840s as well, insofar as many in this cohort would have been in the sensitive adolescent growing years during the mid 1850s. Prices also rose dramatically in other parts of Brazil, suggesting that similar difficulties in obtaining proper nutrition may have affected slaves born outside the city ${ }^{33}$. For slaves, the rapid increase in food costs, and the especially high cost of meat in Rio, may have confronted slave parents with a harsh dilemma ${ }^{34}$. Insofar as they were responsible for feeding themselves and needed sustenance to work, they may have skimped on proteins for their children ${ }^{35}$.

Slaves rented out for general labor (known as escravos de ganho) were sometimes expected to fend for themselves in terms of food and, often, even in terms of shelter ${ }^{36}$. Additionally, when slaves found themselves living under the roof of their owner's house, such as was often the case with cooks and other domestic servants, and were thus subject to their owner's concerns about budgeting for food, periods of scarcity in the city would probably have hit slaves hardest, and children hardest of all. As Steckel puts it for the North American case: «Feeding meat to slave children can be thought of as an investment in which net income was negative during the early years of the investment period because meat was costly and children did not work» ${ }^{37}$.

The changing calculations of owners and parents regarding expenditures on expensive proteins for slave children come into sharper focus when we consider the ratio of unskilled incomes to slave prices. We lack

of foods, shows nearly a quadrupling in prices from a base of 372.6 in 1850 to a peak of 1310.1 in 1860 . This 1856 version, however, is simply not credible, although it does weigh meat more heavily -indicating that the cost of meat was rising much faster than other basic foods.

${ }^{33}$ Evidence of rapid price increases for basic foodstuffs during the 1850 s in the Northeast is found in Mattoso (1992, p. 568 and p. 576). The price level in Salvador, the capital city of Bahia, doubled between 1845 and 1859. Yellow fever and cholera also struck Bahia in 1849-51 and 1855-56 respectively. The cost of living in the countryside, presumably where many slaves were born and raised, remains, for the most part, unknown.

34 Contemporary observers noted that fresh meat in particular saw a dramatic rise in price during the 1850 s and 60 s, see, e.g. Heywood (1864, pp. 245-257, esp. 254). Brazilian authorities were very concerned with the high price of food and its effects, particularly, on the poor (though they did little, in the end, to remedy the situation). See, for instance, Brazil, Ministerio do Imperio, Relatorio do anno de 1856 apresentado a assemblea geral legislativa (Rio de Janeiro: Typ. Laemmert, 1857), p. 53, «carestia de generos alimenticos».

35 Even when meat was provided to poor children, it was mostly in the form of dried beef, which may have been less nutritious than fresh meat. See Kipple (1989, pp. 677-690, esp. 681-82). It should be noted, however, that our data on prisoner heights do not support Kipple's contention that the nutritional status of slaves was significantly worse than that of the free, at least among the poor of Rio de Janeiro during the period under consideration.

36 Mattoso (1986, p. 123); Karasch (1987).

37 Steckel (1989, p. 502). For an additional discussion of this topic, see Steckel, «A Peculiar Sample», p. 234. 
solid data on the returns of slave ownership during the period in question ${ }^{38}$. However, we do know that the ratio of slave prices to the unskilled urban slave wage (derived from slave rental advertisements in the papers) rose significantly from the 1820 s to the 1850 s, from just under $2: 1$ to over $3: 1^{39}$. This fact is important for at least two reasons. First, this would have squeezed the rate of return to slave owners relative to the price of their slaves. Owners may have tried to economize on food, especially expensive proteins, in order to counterbalance this effect. Secondly, and equally importantly, slave parents saw the cost of their own or their children's self-purchased manumission recede with higher slave prices and lower relative incomes. It is possible that the harsh dilemma extended to include the question of whether to adequately feed the child or save for the child's manumission.

If feeding sufficient protein to slave children was always a difficult «investment decision», even in times of relatively stable prices and rising "wages», it must have been all the more so during periods of high prices and scarcity ${ }^{40}$. Indeed, the evidence that slave heights declined in the 1830s-50s suggests the substantial ways in which the lives of slaves diverged from the free. It is commonplace to suggest that slaves and the free poor led similar lives. In fact, in many ways they did. Yet, in the end, slaves were more vulnerable, and slave children and adolescents most vulnerable of all. Infants, up to two years of age, are the most susceptible to stunting on account of poor nutrition, and slave infants were arguably the most vulnerable population in the city ${ }^{41}$.

38 A good preliminary effort, which suggested returns of 11.5 to 15 percent, was made by Pedro Carvalho de Mello (year?) for the 1870s and 1880s. A close look at Carvalho de Mello's paper suggests that food prices weighed heavily in determining the rate of return amounting to about 36 percent of the cost to owners which had to be deducted to find the net hire rate less food, shelter, advertising, and medical care.

39 The values of slaves and slave rental «wages» are reported in Frank (2004, p. 100). The mean slave, both genders, aged $15-40$, circa $1820-25$ was 148 mil-réis. The annual rental "wage», assuming 12 months of work at the prevailing rate set in the advertisements of the Jornal do Commercio, was 80 mil-réis. By 1845-49, the ratio was 421 to 147 mil-réis, rising further to 978 to 300 mil-réis in the years 1855-60.

40 We might also note that the price of slaves rose dramatically after 1831 (initial attempt to suppress the slave trade) and 1850 (successful suppression of the slave trade). Although in the long run, this would seem to make slaves more valuable, and hence lead owners to invest in nutrition, their shorter and medium term decisions were dominated by profit concerns. The length of time it took for a slave to generate "profit" for his or her owner was correlated with slave prices. Spending more money on food for slave children would only have increased this interval further. It follows from this that we predict that lower slave prices (expressed in terms of price/annual earnings of adult slaves) should correlate loosely, ceteris paribus, with periods of greater height. For a relevant discussion of this theme in the North American context, see Komlos and Coclanis (1997, pp. 433-59).

41 Cole (2000, pp. 317-324). Sichieri et al (2000, pp. 77-82) suggest that «the diet of pregnant women may also affect growth, and a low intake of animal protein in late pregnancy 
Not only did slaves born in Rio de Janeiro suffer from nutritional deficiencies, slaves born in Brazil's capital attained systematically lower final heights relative to slaves born in other parts of Brazil. This suggests that problems particular to large and growing urban centers such as Rio had a disproportionate and systematic effect on nutrition and height ${ }^{42}$. As corroboration, observe that the same pattern of lower heights held among female slaves native to the city ${ }^{43}$.

Another possible explanation for declining slave heights, especially in the 1850s birth cohort, would be changing effects of the disease environment — which, incidentally, is not entirely independent of considerations of food costs and urban demographic effects ${ }^{44}$. Most observers at the time noted that slaves seemed to suffer less, not more, from Yellow Fever, although the opposite was the case with cholera ${ }^{45}$. Could it be that lower survival rates hit the poor particularly hard, and that weaker and smaller children succumbed at higher rates while the survivors bore the cost of illness in the form of dietary deficits in critical growing years? Although this is an interesting hypothesis, I hesitate to accept it without reservation. It remains unproven that slaves really did fare differently than the free poor during the worst epidemics. What is uncontestable is that the disease environment shifted during the late 1840s and through the 1850s, with deleterious effects for the residents of Rio de Janeiro, especially the poor -indeed, unskilled free laborers saw their heights decline relative to skilled free laborers. In general terms, poor sanitation and illness, especially afflicting gastrointestinal health, could account for some portion of the low final heights observed among the prisoners in our sample in general.

was associated with low placental and birth weight». Thus, poor neonatal nutrition during the inflationary and disease-ridden years of the 1850s may also have played a role in shorter stature among slaves born in that decade. Furthermore, as Hopkins and Cardell (1992, pp. 310-311) suggest, the «cost» of breast milk was probably higher than the cost of food intake for nursing mothers because some of the energy is lost in the creation of the milk itself.

42 In addition to the problems of high food prices, scarcity, and disease, the city offered an ever diminishing prospect for self-provision. As Komlos (1998) and others have noted, height is related to proximity to food. The rapid urbanization of Rio de Janeiro, beginning in the 1840 s, but surging ahead in the 1850s, would have meant, among other things, less open ground for urban gardens and restricted space for poultry, swine, and other sources of animal protein and fat.

43 For slave women native to the city, heights declined from 1.53 to 1.49 meters over the last two birth cohorts; the figures for all slave women indicate a decline from 1.55 to 1.51 meters.

44 The epidemics coincided with periods of high food prices, but the death and disorder occasioned by disease also disrupted food production and marketing, exacerbating a difficult situation in Rio and other large cities. See Cooper (1986, pp. 467-488) and Matosso (1992, p. 566-567).

45 On yellow fever, see Chalhoub (1996); on cholera, see Cooper (1986). 
The third hypothesis regarding declining slave heights in the 1850s cohort rests on the fundamental institutional and economic shifts that swept the city in the 1840s and1850s. To wit: the Atlantic slave trade ended in 1849-50, in part due to British pressure, in part due to Brazilian internal politics and concerns regarding slave resistance; and, at just the same time, the rural economy, especially coffee, expanded dramatically ${ }^{46}$. Without a source of new African slaves to work in the coffee groves of the Paraíba Valley, planters had to turn to alternative sources of labor after 1849. Over the course of the 1850s (and indeed in the $1840 \mathrm{~s}$ as well), one viable source was the recruitment of slaves from urban centers like Rio de Janeiro and the diversion of other taller slaves from the North and Northeast away from the city and into the coffee fields ${ }^{47}$. Thus, slaves born in the 1851-60 cohort and living in Rio de Janeiro (whether born in the city or elsewhere in Brazil), and who were thus in their prime working years around 1880 , were a slightly but measurably different group than the older cohorts. A disproportionate number of these slaves were «missing» from the Rio de Janeiro jail -working instead, as it were, in the rural sector ${ }^{48}$.

It is possible to measure the relative number of slaves in various occupational categories over the various cohorts. The relevant contrast for our purpose is the 1840s versus the 1850s. Among the latter cohort, the only occupational designation with a decline in numbers is that of general laborer. In the 1841-50 cohort, 41 percent of Brazilian-born male slaves were listed as general laborers, in the 1851-60 group, the proportion of such workers fell to 30 percent, whereas the total number of slaves increased by 1 percent. These general laborers tended to be taller than domestic workers but shorter than free skilled workers. Fewer general laborers may have meant lower mean heights for male nativeborn Brazilian slaves on the whole in the prison sample. It is also noteworthy that all categories of unskilled labor, whether free or slave, see a substantial decline in mean height for the 1841-50 cohort, followed by a recuperation in heights in all groups save the Rio-born slaves. This suggests that something specific about the conditions in the city was affec-

46 There is a vast literature on the rise of coffee and the aftermath of the suppression of the Atlantic slave trade. The classic study of the rise of coffee in Rio de Janeiro province remains Stein (1985 [orig. 1957]). With regard to the effects of the ending of the slave trade in the city of Rio de Janeiro proper, see Frank (2004) and «Wealth Holding in Southeastern Brazil, 1815-1860», HAHR (2005). For a discussion of the internal political factors in the suppression of the Atlantic slave trade, see Needell (2006). For the possible role of slave resistance, see Graden (1996, pp. 249-282). For the British role, see Bethell (1970).

${ }^{47}$ The best study of interprovincial slave transfers is still that of Slenes (1976).

48 Evidence from other places lends further support to our argument. Field hands were an inch, or 2.2 centimeters, taller than domestic slaves in Trinidad, for instance. Fogel et al. (1983, p. 471). 
ting the growth prospects of slaves. The fact that the heights of free unskilled manual laborers born in Rio de Janeiro were lower than free unskilled workers from the Northeast lends further credence to this line of thinking. Among free skilled workers, who presumably earn higher incomes and therefore are cushioned against the worst aspects of the urban penalties of high prices for food and shelter, the natives of the metropolis are as tall, or taller, than their Northeastern counterparts ${ }^{49}$.

TABLE 5

OCCUPATION AND HEIGHTS IN RIO DE JANEIRO - BRAZILIAN-BORN PRISONERS

\begin{tabular}{|l|c|c|c|}
\hline \multirow{2}{*}{\multicolumn{1}{|c|}{ Place of Birth }} & \multicolumn{3}{|c|}{ Birth Cohort } \\
\cline { 2 - 4 } & $\mathbf{1 8 3 1 - 4 0}$ & $\mathbf{1 8 4 1 - 5 0}$ & $\mathbf{1 8 5 1 - 6 0}$ \\
\hline Slave, RJ City, Unskilled* & 1.653 & 1.646 & 1.606 \\
Slave, Northeast, Unskilled & 1.629 & 1.636 & 1.654 \\
Free, RJ City, Unskilled & 1.648 & 1.621 & 1.637 \\
Free, Northeast, Unskilled & 1.675 & 1.656 & 1.672 \\
Free, RJ City, Skilled Manual & 1.699 & 1.654 & 1.654 \\
Free, Northeast, Skilled Manual & 1.677 & 1.657 & 1.650 \\
\hline Number of Observations & & & \\
Slave, RJ City, Unskilled** & 8 & 12 & 18 \\
Slave, Northeast, Unskilled & 7 & 48 & 13 \\
Free, RJ City, Unskilled & 8 & 12 & 22 \\
Free, Northeast, Unskilled & 10 & 24 & 15 \\
Free, RJ City, Skilled Manual & 15 & 12 & 29 \\
Free, Northeast, Skilled Manual & 25 & 24 & 47 \\
\hline
\end{tabular}

Source: see Table 1.

Note:

* Unskilled defined in the register as "workers" (trabalhadores) and "laborers" (jornaleiros).

** Skilled manual laborers, defined as carpenters, cabinetmakers, stonemasons, and painters. Northeast includes North region as well.

It is nevertheless plausible, more generally, that taller slaves of all occupational backgrounds were more likely to be sold to buyers in the rural sector -in fact, there is evidence of this tendency in the slight decline in numbers and large decline in stature of slaves listed with other occupations from the North/Northeast. In addition, there is evidence that

49 There is also evidence that the distribution of heights among native-born slaves booked into the Rio jail became less normal and much more negatively skewed in the last birth cohort. In a normal human height distribution, among males, the standard deviation ought not exceed seven cms. 
slaves who were sold to buyers distant from their place of origin, in this case slaves residing in the capital but born elsewhere in Brazil, tended to be taller than slaves native to the city of Rio de Janeiro. A general tendency toward fewer slaves from outside the city and more locally born would tend to depress heights, as the propensity to divert taller slaves to other locations was greater when slaves moved over long distances ${ }^{50}$.

Finally, with respect to our argument concerning shifts in the composition of the slaves in our prison sample, the standard deviation in height rose dramatically for slaves, especially those born in Rio de Janeiro city, during the period 1851-60. This is consistent with the hypothesis that the population, which had been more or less «normal», had been negatively skewed by the pull of demand for slaves, especially taller, stronger slaves, in the coffee fields of Rio de Janeiro province.

One of the most exciting aspects of the Rio de Janeiro prison records, from the perspective of anthropometric history, is the presence of a good number of women among the observations. Unfortunately, the number of women in our sample is too small at this point to venture strong claims about women and their socioeconomic conditions according to their stature ${ }^{51}$. Notwithstanding this limitation, I argue that taller, stronger women would also have been attractive sources of labor for the plantations. Coffee plantations, in particular, made very extensive use of female labor in the fields ${ }^{52}$. The 1850s birth cohort of slave women residing in Rio de Janeiro was nearly 4 centimeters shorter, at 1.492 meters, than the 1840s group (see Table 5). My working hypothesis is that plantation-driven demand for slaves was biased toward taller slaves to work as field hands because height was considered, ceteris paribus, to be a sign of greater health and vigor: as a consequence taller female slaves were also shifted out of Rio de Janeiro in disproportionate numbers.

It also seems likely that shocks to nutrition hit female slaves hardest of all. To the extent that they were mothers, they faced the «harsh dilem-

${ }^{50}$ In making this assertion, I am aware of the controversy regarding selection bias in inter-regional slave trade in the United States. Pritchett and Freudenberger's critique (1992, pp. 109-127) of the use of coastwise manifests hinges on the idea that slaves shipped coastwise tended to be systematically biased toward taller slaves, particularly taller children. For a critical view of the slave selection argument, see Komlos and Alecke (1996, pp. 437-57). My point is slightly different. I assume that many slaves shipped to Rio de Janeiro city from other parts of Brazil came from rural areas and that, as such, their growing years were passed with better access to nutrition than their counterparts in the city.

51 The Cecult sample yielded 344 usable observations of heights among women prisoners booked into the Rio de Janeiro jail during the same periods covered by the male sample. The sample would need to be several times larger to conduct a more nuanced analysis of women and height in Rio de Janeiro. It is the intention of the Cecult team to pursue this subject in future research and publications.

52 For the labor of women on the coffee plantations, see Stein (1985, orig. 1957). 
TABLE 6

HEIGHTS OF BRAZILIAN-BORN FEMALE PRISONERS IN RIO DE JANEIRO JAIL

\begin{tabular}{|c|c|c|c|}
\hline & All Slave Women & Rio-Born Slave Women & Free Women \\
\hline Birth Cohort & & & \\
$1831-40$ & 1.529 & 1.530 & 1.556 \\
$1841-50$ & 1.553 & 1.492 & 1.515 \\
$1851-60$ & 1.513 & & 1.538 \\
\hline Number of & & & \\
Observations & 35 & 24 & 12 \\
$1831-40$ & 81 & 35 & 14 \\
$1841-50$ & 114 & & 32 \\
$1851-60$ & & & \\
\hline
\end{tabular}

Source: Casa de Detenção, 1860-61 and 1877-80.

ma» suggested earlier in this paper: to feed themselves or to feed their children. Of course fathers felt this dilemma as well, but mothers probably felt it more acutely. Compare the four centimeter drop in mean heights among female slaves (whether native to Rio or to other parts of Brazil) to the much smaller decline $(1.3$ to $1.5 \mathrm{~cm})$ for male slaves native to the city or other parts of the country. Poverty was not gender blind in nineteenth-century Rio de Janeiro, especially among slave women.

In sum, our analysis indicates that the broad trend was stability in the heights of free Brazilians over decadal birth cohorts. In contrast, slave heights declined from levels similar to or above those of the free down to very low mean stature among those born in the 1850s. Heights, on the whole, were low when compared with North American standards from the same period but slightly higher than those found in Spain, Italy, and Portugal around the same time. If final heights are primarily determined by levels of childhood nutrition, then levels of nutrition among the city's poor were low relative to North America and similar or better than levels found in Southern Europe. Conditions for slaves in particular, however, seem to have deteriorated significantly in Rio, registering declines from the 1820 s through the 1850s. The puzzle of declining slave heights seems best explained with reference to declining nutrition, especially in the difficult and expensive urban environment of Rio de Janeiro, along with the end of the Atlantic slave trade and the selective exodus of slaves to the rural sector in response to demand for labor on plantations. Epidemic disease probably accounts for some portion of the decline in slave heights in 1850s. However, I hesitate to push disease as an explanation too far, given that the same negative conditions affected the free poor, yet this group managed to maintain relatively stable heights over the entire period. 


\section{REFERENCES}

BrAzIL, Ministerio do Imperio (1857): Relatorio do anno de 1856 apresentado a assemblea geral legislativa. Rio de Janeiro: Typ. Laemmert.

BRAZIL. (1873-76): Recenseamento da população do Brazil a que se procedeu no dia 1 de agosto de 1872. Rio de Janeiro: Diretoria Geral de Estatística.

\section{BIBLIOGRAPHY}

ARCALENI, E. (2006): «Secular Trends and Regional Differences in the Stature of Italians, 1854-1980». Economics and Human Biology 4:1, pp. 24-38.

Bethell, L. (1970): The Abolition of the Brazilian Slave Trade: Britain, Brazil and the Slave Trade Question. Cambridge: Cambridge University Press.

Carrión, J. M. M. (2001): «Estatura, Salud y Bienestar en las Primeiras Etapas del Crecimiento Económico Español: Una Perspectiva Comparada de los Niveles de Vida», working paper no. 0102, Madrid: AEHE.

CARSON, S. A. (2005): «The biological standard of living in $19^{\text {th }}$ century Mexico and in the American West». Economics and Human Biology 3:3, pp. 405-419.

Carvalho de Mello, P. «Rates of Return on Slave Capital in Brazilian Coffee Plantations», in Fogel and Engerman, «Without Consent or Contract», Technical Papers, Volume 1, especially p. 75.

Снацнов, S. (1996): Cidade febril: cortiços e epidemias na corte imperial. São Paulo: Companhia das Letras.

- (1990): Visões da liberdade: uma história das últimas décadas da escravidão na corte. São Paulo: Companhia das Letras.

Coatsworth, J. H. (1996): «Welfare», American Historical Review 101:1, pp. 1-12.

- (2005): «Structures, Endowments, and Institutions in the Economic History of Latin America». Latin American Research Review 40:3, pp. 126-144.

Cole, T. (2000): «Secular Trends in Growth». Proceedings of the Nutrition Society 59, pp. 317-324.

Cooper, D. (1986): «The New Black Death-Cholera in Brazil, 1855-56». Social Science History 10:4 (winter), pp. 467-488.

Eveleth, P. and Tanner, J. M. (1990): Worldwide Variation in Human Growth. Cambridge: Cambridge University Press.

FLoud, R. (2002): «The achievements of anthropometric history», in M. Smith (ed.), Human Biology and History. London: Taylor \& Francis, pp. 152-164.

Fogel, R. et al. (1983): "Secular Changes in American and British Stature and Nutrition». Journal of Interdisciplinary History 14:2 (Autumn 1983), pp. 445-481.

Frank, Z. (2004): Dutra's World: Wealth and Family in Nineteenth-Century Rio de Janeiro. Albuquerque: University of New Mexico Press.

— (2005): «Wealth Holding in Southeastern Brazil, 1815-1860». Hispanic American Historical Review 85:2 (May), pp. 223-258.

Graden, D. (1996): "An Act "Even of Public Security": Slave Resistance, Social Tensions, and the End of the International Slave Trade to Brazil, 1835-1856». Hispanic American Historical Review 76:2, pp. 249-282.

Heywood, J. (1864): «Resources of Brazil», Journal of the Statistical Society of London, 27:2. pp. 245-257, esp. 254. 
Higman, B. W. (1979): «Growth in Afro-Caribbean Slave Populations». American Journal of Physical Anthropology 50, pp. 373-386.

Holloway, T. (1993): Policing Rio de Janeiro. Stanford: Stanford University Press.

Hopkins, M. and CARDELL, N. S. (1992): «The Relation between the cost of Calories for Suckling Babies and for Nursing Mothers», in R. Fogel, Without Consent or Contract: the Rise and Fall of American Slavery: Evidence and Methods. New York: Norton, pp. 310-11.

Johnson, P. and Nicholas, S. (1997): «Health and Welfare of Women in the United Kingdom, 1785-1920», in R. Steckel and R. Floud, Health and Welfare During Industrialization Chicago: University of Chicago Press, pp. 201-250.

Karasch, M. (1987): Slave Life in Rio de Janeiro, 1800-1850. Princeton: Princeton University Press.

KIPPLE, K. (1989) «The Nutritional Link with Slave Infant and Child Mortality in Brazil». Hispanic American Historical Review 69:4, pp. 677-690.

Komlos, J. (2004): «How to (and How Not to) Analyze Deficient Height Samples: an Introduction». Historical Methods 37:4 (Fall 2004), pp. 160-173.

- (1998): «Shrinking in a Growing Economy? The Mystery of Physical Stature during the Industrial Revolution». Journal of Economic History, 58:3, pp. 779802.

- (1994): «The Stature of Runaway Slaves in Colonial America», in Komlos (ed.), Stature, Living Standards, and Economic Development: Essays in Anthropometric History. Chicago: University of Chicago Press, pp. 93-116.

- (1992): «Toward an Anthropometric History of African-Americans: The Case of the Free Blacks of Antebellum Maryland», in C. Goldin and H. Rockoff (eds.), Strategic Factors in Nineteenth Century American Economic History: A Volume to Honor Robert W. Fogel Chicago: University of Chicago Press, for the National Bureau of Economic Research, Studies in Income and Wealth, Vol. 52, pp. 297329.

Komlos, J. and Alecke, B. (1996): «The Economics of Antebellum Slave Heights Reconsidered». Journal of Interdisciplinary History 26, pp. 437-57.

Komlos, J. and Coclanis, P. (1997): "On the Puzzling Cycle in the Biological Standard of Living: the Case of Antebellum Georgia». Explorations in Economic History 34, pp. 433-459.

Libano SOARES, C. E. (2002): A capoeira escrava e outras tradições rebeldes no Rio de Janeiro, 1808-1850. Campinas: Editora UNICAMP.

LoBo, E. (1978): História do Rio de Janeiro (do capital commercial ao capital industrial e financeiro), 2 vols. Rio de Janeiro: Ed. IBMEC.

LÓPEZ-Alonso, M. (2000): «Height, Health, Nutrition and Wealth: A History of Living Standards in Mexico, 1870-1950», Ph.D. diss., Stanford University.

MARGO, R. and STECKEL, R. (1983): «Heights of native-born whites during the antebellum period». Journal of Economic History 43:1 (March), pp. 167-74.

Martínez Carrión, J. M. (2001): Estatura, Salud y Bienestar en las Primeiras Etapas del Crecimiento Económico Español: Una Perspectiva Comparada de los Niveles de Vida, Madrid: working paper no. 0102 AEHE, appendix, table 1, p. 57.

Matтoso, K. (1992): Bahia, Século XIX. Rio de Janeiro: Nova Fronteira.

- (1986): To be a Slave in Brazil. New Brunswick: Rutgers University Press.

Meisel, A. and Vega, M. (2005): "The Stature of the Colombian Elite Before the Onset of Industrialization, 1870-1919». Banco de la República, Borradores de Economia, paper number 339. 
NeEdell, J. (2006): The Party of Order: The Conservatives, the State, and Slavery in the Brazilian Monarchy, 1831-1871. Stanford: Stanford University Press.

Nogueról, L. P., Shikida, C. D. and Monasteiro, L. M. (2005): «Seis Centímetros: Uma Analíse Antropométrica da Pof 2002-03». ANPEC, Anais do XXXIII Encontro Nacional de Economia, ${ }^{\circ} .159$.

REIS, J. (2004): «Was there an Anthropomorphic Paradox in Portugal?», working paper.

Pritchett, J. and Freudenberger, H. (1992): «A Peculiar Sample: The Selection of Slaves for the New Orleans Market». Journal of Economic History 52:1 (March), pp. 109-127.

SALVATORE, R. and Baten, J. (1998): «Heights and Welfare in Late-Colonial and PostIndependence Argentina", in J. KomLos and J. BATEN (eds.), The Biological Standard of Living in Comparative Perspective. Stuttgart: Franz Steiner Verlag, pp.97-121.

SaLVATORE, R. (2004): «Alturas, Nutrición y Bienestar en la Argentina (1790-1950) Algunos hallazgos recientes y su importancia para la historia económica», manuscript working paper.

SichIERI, R. et al. (2000): "Short Stature and Hypertension in the City of Rio de Janeiro, Brazil». Public Health Nutrition 3:1 (Mar.), pp. 77-82.

SOARES, C. E. L. (2002): A capoeira escrava e outras tradições rebeldes no Rio de Janeiro, 1808-1850. Campinas: Editora UNICAMP.

SLENES, R. (1976): «The Demography and Economics of Brazilian Slavery», Ph.D. diss., Stanford University.

STECKel, R. (1986): «A Peculiar Population: The Nutrition, Health, and Mortality of American Slaves from Childhood to Maturity». The Journal of Economic History 46:3 (September 1986), pp. 721-741.

- (1989): «Work, Disease, and Diet in the Health and Mortality of American Slaves», in R. Fogel, Without Consent or Contract, supplement volume 2. New York: Norton, pp. 489-507.

STEIN, S. (1985, orig. 1957): Vassouras: a Brazilian coffee county, 1850-1900. Princeton: Princeton University Press.

Tadman, R. (2000): «The Demographic Cost of Sugar: Debates on Slave Societies and Natural Increase in the Americas». American Historical Review 105:5 (Dec.), pp. $1534-1575$.

TATAREK, N. (2006): «Geographical height variation among Ohio Caucasian male convicts born 1780-1849». Economics and Human Biology 4, pp. 222-236.

ZupKo, R. E. (1977) British Weights and Measures: A History from Antiquity to the Seventeenth Century. Madison: University of Wisconsin Press 173. 
